\section{Ahmet Özet \\ Gülsüm Özet \\ Zafer Çalışkaner \\ Şeref Kömürcü \\ Fikret Arpacl \\ Önder Berk}

Gülhane Military Medical Academy,

Department of Medical Oncology,

Ankara, Turkey

\title{
Survival with Chronic Myelogenous Leukemia: The Outcome of a Patient Who Had One of the Longest Survivals
}

In June 1997, on follow-up examination, whole blood count revealed leukocytosis and anemia (white blood cells (WBC) 120,000/ $\mathrm{mm}^{3}$ and hemoglobin $7 \mathrm{~g} / \mathrm{dl}$ ). Since peripheral blood smear and bone marrow examination were not concordant with the blastic phase, this progression was accepted as an accelerated phase of CML. Leukapheresis and erythrocyte transfusion were performed and hydroxyurea increased from 500 to $2,000 \mathrm{mg} /$ day. Next, the hydroxyurea dose was reduced to $1,000 \mathrm{mg} /$ day after the WBC count fell to $<20,000 / \mathrm{mm}^{3}$. Two months later, the patient was hospitalized with fever, nausea, vomiting and coughing. WBC count was $28,700 / \mathrm{mm}^{3}$, hemoglobin 8.1 $\mathrm{g} / \mathrm{dl}$ and platelet count $133,000 / \mathrm{mm}^{3}$. Repeated blood, throat, sputum and urine cultures were negative. Fever was controlled with empiric antimicrobial treatment. Five days after admission, acute respiratory dis- tress suddenly developed. He failed to respond to emergency treatment and died due to respiratory arrest in August 1997.

202 months' survival (from November 1980 to August 1997) is one of the longest survivals among patients with CML. In fact, to the best of our knowledge, up until now only 1 patient with a 17-year survival has been reported by Salvagno et al. [2].

\section{References}

1 Özet A, Özet G, Calışaner Z, Kömürcü S, Arpac1 F, Berk Ö: Survival with chronic myelogenous leukemia (letter). Oncology 1997;54: 516.

2 Salvagno L, Soraru M, Leszl A, Koussis H, De Franchis G, Fiorentino MV: Prolonged survival (17 years) in a patient with chronic myelogenous leukemia after therapy for Hodgkin's disease. Leuk Lymphoma 1994;16:177-181.

\section{KARGER}

Fax +41613061234

E-Mail karger@karger.ch www.karger.com (c) 1998 S. Karger AG, Basel

0030-2414/98/0556-0607\$15.00/0

Accessible online at: http://BioMedNet.com/karger
Ahmet Özet, MD

Gülhane Military Medical Academy Department of Medical Oncology

Ankara (Turkey)

Fax +90312321 7778 